\title{
FEASIBILITY ANALYSIS OF A HYBRID TEACHING METHODOLOGY USING DATA ANALYSIS IN THE FEDERAL UNIVERSITY OF RIO GRANDE DO SUL ENGINEERING SCHOOL
}

DOI: 10.37702/2175-957X.COBENGE.2021.3531

Lucas dos Santos Azevedo - radialistalucasazevedo@outlook.com Universidade Federal do Rio Grande do Sul Rua José de Alencar 1318 90880-480 - Porto Alegre - RS

Tiago de Oliveira Belmonte - belmontetiago0@gmail.com Universidade Federal do Rio Grande do Sul Rua Getúlio Vargas 810 95625-000 - Imbé - RS

Luiz Fernando Garcez Scherer - Luiz-f2121@hotmail.com Universidade Federal do Rio Grande do Sul Rua Silva Só 79 90610-270 - Porto Alegre - RS

Talita Braun Dalla Porta - talita.braun.uf@gmail.com Universidade Federal do Rio Grande do Sul Oswaldo Pereira de Freitas 135 91530-080 - Porto Alegre - RS

Alexandre Narvaz - narvaz.alexandre@gmail.com Universidade Federal do Rio Grande do Sul Rua Eurico Lara 143 90880-390 - Porto Alegre - RS

Giovanni Falcão Mendes - giovannimendes800@gmail.com Universidade Federal do Rio Grande do Sul Rua Duque de Caxias, 15761576 90010-281 - Porto Alegre - RS

Guilherme Vanni de Miranda - guilherme.v.miranda@gmail.com Universidade Federal do Rio Grande do Sul Rua General Goes Monteiro 500 
95703-052 - Bento Gonçalves - RS

Simone Ramires - simone.ramires@ufrgs.br Universidade Federal do Rio Grande do Sul

Praça Argentina 9

90040-020 - Porto Alegre - RS

Resumo: Faced with the coronavirus pandemic, emergency remote education was adopted by most higher education institutions in the world. Considering the sudden transformations and challenges in this context and the delay of public universities in evolving their teaching methods and processes in contrast to technological evolution, this research aims at a Hybrid Teaching project initially developed within the School of Engineering at the Federal University of Rio Grande do Sul, for the implementation and offer of a distance learning system together with face-to-face teaching at a later time the pandemic, taking into account technical, economic, logistical and social factors of students and teachers using data analysis tools and technical advice and systematic research for further measurement of success and replication in other courses within the University.

Palavras-chave: Hybrid teaching. Engineering. Technology. 


\section{FEASIBILITY ANALYSIS OF A HYBRID TEACHING METHODOLOGY USING DATA ANALYSIS IN THE FEDERAL UNIVERSITY OF RIO GRANDE DO SUL ENGINEERING SCHOOL}

\section{INTRODUCTION}

The last two decades have been marked by a great technological advance with the consolidation of the Internet and the transformation in the way of managing in a globalized world. These forces of change have required organizations to be much more agile and to have greater responsiveness to the changes and demands of a continuously changing market. The digital age enables companies to know the needs of consumption and desire of groups of people, or even other companies, better understanding the means to offer products and services. Increasingly, innovation and agility in actions and decisions are fundamental for the survival of organizations in the face of a globalized market.

Technology has enabled individuals and small organizations to connect with the "collective knowledge" of the world to create fantastic opportunities for collaboration in supply chains. The natural consequence of this phenomenon is that the world has "leveled". In other words, traditionally underdeveloped countries such as China and India have been trained and can participate more easily in the global economy. The world no longer leans towards countries like the United States and European nations in terms of economic advantage. Technology has improved the outsourcing of developed economies (COYLE et al, 2013).

Technology has had a significant effect on supply chains as a facilitator of change as companies transform their processes. However, it is also an important force in changing market dynamics. Individuals and organizations are connected 24 hours a day seven days a week. Search engines like Google have made it possible to collect timely data instantly. We no longer must wait for the media to "push" information at us on their own agenda; we can "pull it" as we need to. Social networks such as Facebook and Twitter play an increasingly important role in companies and will influence supply chains due to their impact on customer demand and the speed of information transfer. Many companies see opportunities to apply data mining to short instant messages of 140 characters or less (tweets) in order to discover demand-related information and build more accurate forecasts (COYLE et al, 2013).

In this sense, a data platform or Big Data term is used to define a large set of IT tools that allow the capture, analysis, and cataloging of records in real-time is essential as a tool for management and control of the data obtained, through the structuring and control of data allowing access and management of information instantly, and from its application the internet of things or internet of things (IOT).

The information can be sourced from different internal sources and External, such as customer registrations, market analysis, social networks, electronic devices, internal processes, or even research in offline media. The advantage of these tools is to centralize, in a single place, the collection, and analysis of this large set of records (NEOWAY, 2019).

In contrast to the fourth industrial revolution, or Industry 4.0, data analysis can be applied to numerous logistical situations, in market-changing goods that develop and introduce new network solutions, including loT technology and robots (PAPROCKI, 2017), 
and in the formulation of efficiency and control models (ZAMCOPÉ et al, 2010; WANKE, AFFONSO, 2010, CICOLIN; OLIVEIRA, 2016).

\section{METHODOLOGY}

This research project uses a mixed approach methodology. Qualitative in the sense that seeks to make an analysis of the nature of the object of study (a form of teaching), problems involved in the context of its use (environmental, social, logistics economy, and sustainability) with the dynamic relationships of its use nowadays. Quantitative as it seeks to make a quantitative analysis of data obtained and implementation of statistical tools (FONSECA, 2002; GERHARDT, 2009).

As for nature, this is an applied research with the objective of generating knowledge for practical application, aimed at solving specific problems (GERHARDT, 2009).

As for the objective, it is characterized as exploratory providing greater familiarity with the problem, with a view to the construction of hypotheses, as descriptive, in the sense that describes and characterizes concepts, as well as explanatory, by analyzing, verifying, evaluating, comparing, and explaining the data obtained (GIL, 2007; MATTOS, 2019).

As for technical procedures, the project is characterized as experimental research since it determines an object of study and selects variables that can influence it, thus defining forms of control and observation (GIL, 2007).

Field research, having as characteristic the investigative process using different forms of data collection, such as bibliographic, documentary and survey that technical information about the object of study (FONSECA, 2002).

Thus, it is primarily a case study that will be carried out with a focus on data collection, analysis, and implementation of a hybrid teaching system in engineering courses (initially, the offer can be extended to other courses after the case study) at the Federal University of Rio Grande do Sul (UFRGS), enabling a more dynamic and efficient teaching process using distance learning methodologies together with the offer of face-to-face teaching (YIN, 2015).

Also, according to Yin (2015), it is characterized as a case study, because it investigates a contemporary phenomenon within its real-life context, facing a unique situation, with several variables and sources of evidence.

\section{HYBRID SYSTEM}

\subsection{What is the education system?}

The concept of the Education System has been changing to accompany the transformations in education. Currently, it is described as: The Education System can be understood as a business model that offers a set of educational solutions (among a range of products and services) to meet the most varied needs and demands of educational institutions" (SAE, 2019).

\subsection{Need to align technology with teaching:}

The globalization of information and the possibility of real-time access determines that education adapts to social demand, using more creative resources, to develop skills of selective search of useful information, current and immediate application, with the objective of training autonomous individuals capable of dealing with new technologies and new languages. 


\subsection{Definition and concept of hybrid teaching:}

Hybrid teaching is a pedagogical approach that combines face-to-face activities and activities carried out through digital technologies and information and communication. There are several proposals for implementing this system, but the main idea is to focus on the learning process of the student and no longer on the transmission of information through a traditional method. According to the approach, curriculum contents are not transmitted by a teacher in the classroom. The student studies in different situations and environments, and the classroom becomes the place to actively learn, performing activities and projects, discussions, laboratories, etc. Hybrid teaching follows a trend that has occurred in virtually all services and processes in society, such as banking services, commercial services, and companies. All these transformations caused the focus of the activities, which were previously on the agents that provided the services, to pass to users (BACICH, NETO, DE MELLO TREVISANI, 2015).

Considering that in this new cultural text that is configured in times of Digital Information and Communication Technologies (ICT), the mediation of hybrid teaching is made possible by different digital contexts, such as the Internet, accessed by various devices: computers, tablets, smartphones (MARTINS, 2016).

Hybrid teaching, or blended learning, is one of the educational trends of the 21st century, in which its pedagogical approach combines face-to-face activities and activities carried out through digital technologies (BACICH; TANZI NETO; TREVISANI, 2015).

There are several proposals for implementing this system, but the main one is to put the focus of the learning process on the student; thus, the transmission of information would not be passed exclusively within the classrooms, through traditional methods. $(\mathrm{BACICH}$; NETO; DE MELLO TREVISANI, 2015).

In hybrid teaching, the student will go to the classroom class after conducting his studies in an AVA (Virtual Learning Environment), in which the teacher can apply knowledge already acquired, carry out projects, promote debates and discussions. Thus, instead of the teacher spending hours transmitting content and taking questions, the student must have studied previously, and can then apply his knowledge in practical activity (SPINARDI; BOTH, 2018).

Education is not only based on teaching but also contributing so that the student can have autonomy in their learning, on the systemic reflection on the most varied topics that surround society. In this way, the individual becomes the author of his own formation. In addition, the educator begins to have the role of mediator and advisor in the formation of a citizen student, in addition to his/her professional training (CRUZ, 2016).

Hybrid education follows a trend of change that has occurred in virtually all services and processes in society, such as banking services, commercial services, and companies. All these transformations caused the focus of the activities, which were previously on the agents that provided the services, to pass to the users. (BACICH; NETO; DE MELLO TREVISANI, 2015).

\subsection{UFRGS teaching model within the School of Engineering and its legislation:}

\section{RESOLUTION No. 10/2006}

THE COUNCIL OF TEACHING, RESEARCH AND EXTENSION, in session of 08/03/2006, considering Decree No. 5,622 of December 19, 2005 and Ordinance MEC No. 4,059 of December 10, 2004 and in view of the information set out in case No. 23078,000326/06-99, pursuant to Opinion No. 
06/2006 of the Committee on Guidelines for Teaching, Research and Extension,

\section{Solves}

establish the following STANDARDS FOR REGULATION OF DISTANCE EDUCATION ACTIONS, WITHIN THE UFRGS:

Art. 4 - Distance education actions can be classified as:

I - distance learning activity - any of the types of teaching activity provided for at the University (discipline, curricular internship, teaching internship and completion work) in which more than $20 \%$ of the workload involves distance learning activities.

II - distance learning course - a course in which more than $20 \%$ of the total workload is composed of distance learning activities.

III - distance extension action - extension actions in which more than $20 \%$ of the workload involves distance activities.

Sole paragraph - UFRGS face-to-face courses may offer distance learning activities, in accordance with legal limitations (UFRGS, 2006).

\subsection{Global hybrid teaching model}

Hybrid teaching models could be grouped into 6 classes through a Systematic Literature Mapping (MSL) (SCHIEHL and GASPARINI,2017). Because it is a recent subject and, in most articles, does not yet receive a specific name that makes a distinction between types, the examples of HE were gathered according to the characteristics, in the following 6 groups by similarity, they are:

- Supplementary: predominance of classroom study and subsequent complementation of studies remotely;

- Inverted classroom: The beginning of studies remotely and later development in the classroom of concepts and projects;

- Rotational Laboratory: Traditional classroom activities and computerized activities in laboratories of the institution;

- Rotation of Studies: Studies with 2 different teachers, one for physical classroom scans, one for virtual class;

- Synchronous Collaborative Hybrid: Availability to choose from various combinations such as synchronous, asynchronous, face-to-face virtual class, and mergers. All with the teacher available for guidance through chat rooms, email, and platforms, synchronous and asynchronous;

- Dual-Collaborative Group: A protected platform for interaction of students and a facilitator/teacher, through videos, debates experiences, to build knowledge. (SCHIEHL and GASPARINI,2017).

Through the MSL, the prevalence of hybrid education (HE) was verified in Higher Education Institutions (85\%), where Brazil stands out in the number of papers on the subject (19\%). Regarding the type of HS, the predominance of the Supplementary model $(62.5 \%)$ is still close to the traditional model, not generating a break in the teaching style, unlike the second most used type, which is the Inverted Classroom (21.9\%) which brings a great transformation in the traditional teaching model, the other 4 modalities add up (15.6\%) (SCHIEHL and GASPARINI, 2017).

Also, according to an experiment in 18 classes of different courses, in physics discipline 1, at the University of Brasília, there was an increase in the percentage of approvals of the discipline from $27 \%$ (from $41 \%$ to $52 \%$, maintaining face-to-face evaluations) and reduction in the locking of the discipline from 15\% (from 19\% to 16\%) (MONTEIRO, Fabio, 2021). The model implemented was a mixture of synchronous 
collaborative hybrid and dual-collaborative groups according to the previously grouped models.

\section{DATA ANALYSIS}

\subsection{Modern definition}

In the age of technology, data analysis is one of the main tools when it comes to making decisions strategically. More than simply capturing information and doing a reading, analysis helps you understand what society generally needs. When analyzed effectively and used from a strategy, the data can result in the development and optimized business management capability.

Data analysis can be seen as the process of developing decisions or practical recommendations for actions based on glimpses generated by previously collected data. According to the Institute for Operations Research and Management Science (Informs), data analysis represents the combination of computerized technology, administrative science technique, and statistics to solve real problems. The idea of looking at all the data to understand what is happening, what will happen and how to get the best out of it was overlooked by Informs, by proposing three levels of data analysis. These three levels are identified as descriptive, predictive, and prescriptive, suggesting that these three levels represent somewhat independent steps, and that one type of data analysis application leads to another. Descriptive data analysis concerns knowing what is happening in the organization and understanding trends and underlying causes of such occurrences. Predictive data analysis aims to determine what is most likely to happen in the future. And finally, prescriptive data analysis recognizes what is happening, as well as what should happen, and make decisions to ensure the best possible performance (SHARDA; DELEN; TURBAN, 2019).

\subsection{Data analysis tools}

Data analysis presents itself as a challenge for qualitative research in several fields of knowledge. The management of large volumes of data from field notes, documents, focus groups, participant observation and interviews require the adoption of rigorous methodological procedures involving the collection, storage, processing, and retrieval of information.

Software support extends the researcher's ability to handle large volumes of data, difficult to be handled manually, requiring only mastery over the resources available to improve analysis and sustain the interpretive processor (CÚRCIO, 2006).

Different software offers different resources for qualitative data analysis, and some of them make use of coding procedures, grouping by word search and verbal expressions (SOUSA, 2020).

Data analysis techniques vary depending on the research strategy as well as the nature of the variables. Variables can be divided into quantitative and qualitative variables. It is also necessary to know the type of tests that can be applied against the variables that were built (RODRIGUES, 2011).

According to Campos (2017), a research has several steps to be followed, and several obstacles may arise in its execution, mainly related to ignorance and non-familiarity with the methods and techniques employed. Regarding the data analysis phase, attention is given to choosing appropriate methods and techniques to provide data exploration in all its richness and possibility. 
Software support extends the researcher's ability to handle large volumes of data, difficult to be handled manually, requiring only mastery of the resources available to improve the analyses and sustain the interpretive process (CURCIO, 2006).

Since the 1908s, many software has been created to assist in the analysis of qualitative data. To refer to them, it is common to use the acronym CAQDAS (Computer-Aided Qualitative Data Analysis software). Several CAQDAS serve to manage data, text research, construction of conceptual maps and theory construction based on coding and recovery activities (LAGE; GODOY, 2008).

Although each application has unique features, there is a convergence in relation to the main functionalities that software can have. Most packages can be described as an application for data storage, indexing, and retrieval, making it easier to apposition of code to datasets and retrieval of all threads that share the same code. In more sophisticated programs, there are tasks such as building relationships between data segments belonging to the same text, developing arrays with cross-tabulation of variables. (WEITZMAN, 2000).

The main software has facilities for encoding the data (assigning names for parts of texts, according to the researcher's specifications). The coded texts can be regrouped, researched and re-encoded, facilitating the generation of ideas and new theories, in a process of proximity between the researcher and his data. At any time, the researcher can return to the original text, as well as review the coded text in its context (JOHNSTON, 2006).

In addition, Johnston (2006) understands that it is interesting that CAQDAS is used from the moment the data collection stage begins, in the phase of theoretical reference organization.

- Example of tools:

WebQDA: The benefits of WebQDA lie mainly in its intuitive interface, data storage, research, and recovery mechanisms, all in a distributed environment that provides collaborative research (SOUZA, COSTA, MOREIRA, 2011).

Knime Analytics: The platform helps you manipulate, analyze, and model data through visual programming. The tool has integrated modules and tools to assist in predicting trends. (MCZ, 2020).

R: Programming language used to do linear and nonlinear modeling, statistical tests, classification, and grouping. (MCZ, 2020).

MATLAB: Data analysis software that supports big data processes. Allows you to access data from multiple sources and formats (MCZ, 2020).

\section{EXPECTED RESULTS AND FINAL CONSIDERATIONS}

Data analysis aims to verify patterns/behavioral scans in various areas of reality, through research that provides consistent data that can be taken to solve problems or even predict them, thus avoiding them.

As a support tool for the implementation of Hybrid Education, data analysis will take place through the collection of information focused mainly on the transportation of students, teachers, and employees of UFRGS and the hourly table of the disciplines offered, verifying the feasibility and the possibility of improvement, given the great problem in the distance and time between campuses. Through research in scientific articles, a methodology of activity diary was located, where in addition to recording the displacements of the interviewees also covers information about the level of education, family members who reside together among others, so that they could perform a mapping of the transport flows needed for the city.

In addition, it is important to highlight the importance of collecting costs and resources involved in data analysis, from the collection of information (which may already be available 
or there is a need for collection) to the processing of data (through software such as Excel) and obtaining applicable knowledge, which will be introduced in the reports made available to UFRGS to evaluate the actions taken and to take as to schedules of disciplines, the feasibility of implementing the HE and other actions that are requested from the team's consulting.

Specifically, in the case of UFRGS, the public would be the ones mentioned above, which have a connection with the institution and the goal will be to find the classes that are not in great condition of realization, thus offering alternatives such as HE or changes in schedules.

As a possibility of applying data analysis to improve the Institution and a good implementation of hybrid education, it aims at the following actions and analyses:

-Evaluation of the feasibility of the groups of disciplines to be enrolled, as to the time of displacement required between them;

-Need of students of available time to perform extra class activities (Extension, Research, Internship, etc.);

-Use of the UR (university restaurant) according to day and time to optimize the processes of the kitchen team;

-Relate the performance in certain subjects and the routine of students to check how and in which disciplines hybrid teaching could best fit;

-Understand if there is a specific group that supports/refutes hybrid teaching and the technical reason for;

-Implementation of pilot classes/disciplines using distance or hybrid teaching methodology according to the best study criteria.

It is still expected that this study can serve as a basis in the future for successful replication in other courses within UFRGS and in other universities that have not yet joined the hybrid education system as a methodology of technological resource, and this is a global trend.

\section{REFERENCES}

BACICH, Lilian; NETO, Adolfo Tanzi; DE MELLO TREVISANI, Fernando. Ensino híbrido: personalização e tecnologia na educação. Penso Editora, 2015.

CAMPOS, Claudinei José Gomes. Método de análise de conteúdo: ferramenta para a análise de dados qualitativos no campo da saúde. Revista brasileira de enfermagem, v. 57, n. 5, p. 611-614, 2004.

CICOLIN, Lucas de Oliveira Melo; OLIVEIRA, Andréa Leda Ramos de. Avaliação de desempenho do processo logístico de exportação do milho brasileiro: uma aplicação da análise envoltória de dados :: dea. Journal of Transport Literature, [S.L.], v. 10, n. 3, p. 30-34, set. 2016. FapUNIFESP (SciELO). http://dx.doi.org/10.1590/22381031.jtl.v10n3a6.

MCZ. Conheça 7 ferramentas para análise de dados. 2020. Disponível em: https://www.maceio40graus.com.br/noticias/conheca-7-ferramentas-para-analise-dedados/. Acesso em: 26 fev. 2021

COYLE, John J. et al. Administración de la cadena de suministro: una perspectiva logística. Cengage Learning, 2013. 
CRUZ, José Anderson Santos; ARXER, Eliana Alves; BIZELLI, José Luís. Ensino Híbrido e as TIC no Ensino Superior. In: INTERCOM. SOCIEDADE BRASILEIRA DE ESTUDOS INTERDISCIPLINARES DA COMUNICAÇÃO; XXXIX CONGRESSO BRASILEIRO DE CIÊNCIAS DA COMUNICAÇÃO. 2016.

CÚRCIO, Verônica Ribas. Estudos estatísticos de textos literários. Texto Digital, v. 2, n. 2, 2006.

FONSECA, J. J. S. Metodologia da pesquisa científica. Fortaleza: UEC, 2002. Apostila.

GERHARDT, Tatiana Engel (org.). Métodos de Pesquisa. Porto Alegre: Ufrgs, 2009. 120 p.

GIL, A. C. Como elaborar projetos de pesquisa. 4. ed. São Paulo: Atlas, 2007.

JOHNSTON, L. Software and method: reflections on teaching and using QSR NVivo in doctoral research. International Journal of Social Research Methodology, v. 9, n. 5, p. 379391, Dec. 2006.

LAGE, Maria Campos; GODOY, Arilda Schmidt. O uso do computador na análise de dados qualitativos: questões emergentes. RAM. Revista de Administração Mackenzie, v. 9, n. 4, p. 75-98, 2008.

MARTINS, Lilian Cassia Bacich. Implicações da organização da atividade didática com uso de tecnologias digitais na formação de conceitos em uma proposta de Ensino Híbrido. 2016. Tese de Doutorado. Universidade de São Paulo.

MATTOS, Sandra. Como elaborar objetivos de Pesquisa. Unesav, S/D. Disponívelemhttp://unesav. com. br/ckfinder/userfiles/files/Como\% 20elaborar\% 20Objeti vos\% 20de\% 20Pesquisa. pdf. Acesso no dia, v. 8, n. 04, 2019.

MONTEIRO, Fábio. Análise de uma experiência híbrida no ensino de Física 1. REVISTA BRASILEIRA DE ENSINO DE FÍSICA, vol. 43, e20200315. 2021

NEOWAY. Big Data: o que é, importância e como aplicar na sua empresa. 2019. Disponível em: https://blog.neoway.com.br/o-que-e-bigdata/?utm source=google\&utm medium =cpc\&utm term=\&utm content=g\&gclid=CjwKCA iAkJKCBhAyEiwAKQBCkv8y1odAr--mmvIKT6hKMy-xL 8HucpEWticlPvgqdtDMQd9XEw3xoCr oQAvD BwE. Acesso em: 07 mar. 2021.

NOVAES, A. G. Logística e gerenciamento da cadeia de distribuição. 3. ed. Rio de Janeiro: Elsevier, 2007

PAPROCKI, Wojciech. How Transport and Logistics Operators Can Implement the Solutions of "Industry 4.0". Sustainable Transport Development, Innovation And Technology, [S.L.], p. 185-196, 2017. Springer International Publishing. http://dx.doi.org/10.1007/978-3319-51427-7 16.

RODRIGUES, Miguel. O tratamento e análise de dados. Metodologia para a investigação social, p. 179-230, 2011.

SCHIEHL, Edson; GASPARINI, Isabela. Modelos de Ensino Híbrido: Um Mapeamento Sistemático da Literatura, 2017. 
SHARDA, Ramesh; DELEN, Dursun; TURBAN, Efraim. Business Intelligence e Análise de Dados para Gestão do Negócio. 4. ed. Porto Alegre: Bookman, 2019.

SAE. Sistema de ensino: Tudo o que você deveria saber! 2019. Disponível em: https://sae.digital/sistema-de-ensino/. Acesso em: 26 fev. 2021

SOUSA, Yuri Sá Oliveira et al. O uso do software Iramuteq na análise de dados de entrevistas. Revista Pesquisas e Práticas Psicossociais, v. 15, n. 2, p. 1-19, 2020.

SOUZA, Francislê Neri; COSTA, António Pedro; MOREIRA, António. Análise de dados qualitativos suportada pelo software webQDA. In: Atas da VII Conferência Internacional de TIC na Educação: Perspetivas de Inovação. 2011. p. 49-56.

SPINARDI, Janine Donato; BOTH, Ivo José. Blended learning: o ensino híbrido e a avaliação da aprendizagem no ensino superior. Boletim técnico do senac, v. 44, n. 1 , 2018.

UFRGS. Resolução no 10/2006, de 08 de março de 2006. Resolução № 10/2006. Porto alegre, RS, 08 mar. 2006. p. 1-2. Disponível em: http://www.ufrgs.br/cepe/legislacao/resolucoes-normativas/resolucao-no-10-2006-de-0803-2006-1/view. Acesso em: 06 maio 2021.

WANKE, Peter Fernandes; AFFONSO, Camila Rodrigues. Determinantes da eficiência de escala no setor brasileiro de operadores logísticos. Production, [S.L.], v. 21, n. 1, p. 53-63, 24 set. 2010. FapUNIFESP (SciELO). http://dx.doi.org/10.1590/s010365132010005000045 .

WEITZMAN, E. A. Software and qualitative research. In: DENZIN, N. K.; LINCOLN, Y. S. (Ed.). Handbook of qualitative research. 2. ed. Thousand Oaks: Sage, 2000. p. 803-820.

YIN, Robert K. Estudo de Caso: Planejamento e métodos. Bookman editora, 2015.

ZAMCOPÉ, Fábio Cristiano; ENSSLIN, Leonardo; ENSSLIN, Sandra Rolim; DUTRA, Ademar. Modelo para avaliar o desempenho de operadores logísticos: um estudo de caso na indústria têxtil. Gestão \& Produção, [S.L.], v. 17, n. 4, p. 693-705, dez. 2010. FapUNIFESP (SciELO). http://dx.doi.org/10.1590/s0104-530x2010000400005.

summary: Faced with the coronavirus pandemic, emergency remote education was adopted by most higher education institutions in the world. Considering the sudden transformations and challenges in this context and the delay of public universities in evolving their teaching methods and processes in contrast to technological evolution, this research aims at a Hybrid Teaching project initially developed within the School of Engineering at the Federal University of Rio Grande do Sul, for the implementation and offer of a distance learning system together with face-to-face teaching at a later time the pandemic, taking into account technical, economic, logistical and social factors of students and teachers using data analysis tools and technical advice and systematic research for further measurement of success and replication in other courses within the University.

Keywords: Hybrid teaching. engineering. technology. 